Ritrýnd grein birt 31. desember 2020

\title{
Surfing a Steep Learning Curve: Academics' experience of changing teaching and assessment due to COVID-19
}

\author{
Guðrún Geirsdóttir, Marco Solimene, Ragna Kemp Haraldsdóttir and Thamar Heijstra \\ Abstract Um höfunda \\ About the authors \\ Heimildir
}

A four week assembly-ban was declared in March 2020 in order to protect the Icelandic population from the COVID-19 pandemic. This meant that the academic staff of the University of Iceland (UI) had to replace on-campus teaching with online teaching, while all vocational and clinical activities were suspended. Some UI academics had experienced digital teaching already, but for many this meant facing a steep learning curve. This paper examines how academic teachers dealt with a sudden shift in their teaching practices during COVID-19.

The research context is a significant network created at the postgraduate diploma Teaching Studies for Higher Education at the UI. There, three academics experienced the unprecedented role of simultaneous teaching and learning during COVID-19. Parallel, a learning process took place where different experiences, stories and reflections were shared which permitted these academic colleagues to act as critical friends. They took notes and applied their learning to their courses while supported by each other and their supervisor.

The data for this study derive from Q\&A notes as well as from shadowing logs from teaching observations within the significant network. Secondary data consists of interactions and emails from students, student evaluations of teaching (SET) as well as email correspondence of the UI Rector to academic staff during the pandemic.

The data reveal that despite being pushed outside their comfort zone in many aspects of teaching, interactions and technology, the teachers managed to fulfil different roles and the experience became a drive towards improvement in their teaching. Their experiences show the implications of COVID-19 for future teaching at UI. Finally, the study emphasizes the importance of peer-learning, peer support and feedback from colleagues in professional development when the learning curve is steep.

Keywords: COVID-19, professional development, student-teacher interaction, online teaching, critical friend

\section{Introduction}

On January 27, 2020, a state of uncertainty was declared in Iceland in response to the outbreak of COVID-19. The Directorate of Health, the Department of Civil Protection and Emergency Management, and the Icelandic Government applied immediate assembly restrictions to the whole country. On March 11, the University Emergency Response Board urged faculty heads, department heads, faculty administrative officers, and other administrators to familiarize themselves with 
options for distance learning and web conferencing to ensure that teaching would continue. This message was followed the very next day by a ban on all teaching on the university premises. Students were reassured that the academic staff was working hard to organize teaching online. On March 22, when the first Icelandic fatality was reported, restrictions included a 20-person assembly limit and a two-meter social distancing rule. Operations of elementary and primary schools were restricted and teaching on premises was suspended for upper secondary schools and universities, which had severe consequences for academic teaching. During the assembly ban, the Rector sent regular announcements to the staff with the slogan Together we will Prevail. The announcements were both informing and encouraging and expressed gratitude towards students and staff. The time to act was limited and called for instant resolutions. The Rector reassured students by pointing out that teachers were "hard at work reorganizing courses into digital format and progress [was] exceeding expectations". At this point in time students' greatest concern was the upcoming final examinations.

On March 23, the Rector announced that arrangements for examinations and assessments would be determined before March 30 by the individual schools and faculties within UI in consultation with the Division of Academic Affairs. Schools, faculties and teaching staff were asked to take into consideration "the challenging circumstances in which we find ourselves and to ease the pressure on students regarding assessment, where possible". The Rector also stated that student representatives would be consulted on changes to the implementation of examinations and assessment and stressed unanimous agreement from the deans of the schools to reduce exam pressure on students as much as possible. On March 31st, two weeks after the assembly ban, all examinations and assessments had been revised. Due to the approach taken, assessment methods differed between courses, disciplines, and schools as academic teachers were given free rein to revise their practices. Additionally, some established restrictive rules were abandoned, and new ones were adopted to give students more leeway.

Parallel to the commotion caused by the pandemic, several studies were conducted to capture the experiences of students. The first one was in March on behalf of the Student Council of UI. Its purpose was to get a better picture of the status and well-being of students during COVID-19. The results were striking, as $53 \%$ of students were experiencing considerable stress and/or pressure that was affecting their learning progress (Stúdentaráð Háskóla Îslands, 2020a). Another survey focusing on job prospects and well-being of students was sent out in May in cooperation with the Ministry of Education, Science and Culture (Háskóli Íslands, 2020). The results showed the serious state of the mental health of students as $47 \%$ rated their mental health at 5 or lower on a 10-point scale where 10 was the best mental health (Stúdentarád Háskóla Íslands, 2020b).

Scholars at the School of Education carried out an institutional-wide survey of students' experience (Björnsdóttir \& Jóhannsdóttir, 2020). According to their findings, the majority of students at UI appreciated the teachers' efforts to redesign their courses and assessment methods and were satisfied with the teachers' use of technology and digital tools. The results indicated that the students hoped that the experience would lead to future modernization of teaching. On the negative side, the students complained about lack of coherence in the reorganisation of courses.

Few domestic studies have focused on the experiences of academic teachers despite the enormous task faced in restructuring their teaching, including curriculum and assessment. Gunnarsdóttir and Pálsdóttir (2020) studied the impact of COVID-19 on the working conditions of UI staff in May 2020. Their study was quantitative and the response rate was $41 \%$. The results show that academics felt less productive than normally in their research activities. Part of the reason was that due to the assembly ban staff members had their children at home and not all academics had access to a separate room to work in or proper tools to work with from home. The results also revealed that $94 \%$ of the academic staff used digital solutions to teach while only $23 \%$ had previous experience in online teaching. In addition, $47 \%$ felt added pressure during the assembly ban. They claimed this was due to intensified interactions with students and the requirement to be more lenient towards students regarding assessment. The majority of respondents claimed that they were considering the possibility of using the changes they had made in their didactics in future teaching post-COVID. 
The percentage varied between different schools within UI where $48 \%$ of the academic staff in the School of Engineering and Natural Sciences and 67\% in the School of Health Sciences felt that they were rather likely or very likely to change their teaching methods permanently.

Within a fortnight, most of the UI teachers had to make swift curriculum changes, reconstruct their previously planned assessment and examination practices, learn how to manage new technology, organise online teaching, and adhere to the Rector's insistence of easing pressure on students.

While the studies above provide an overview of the impact of COVID-19 on students and staff, this study is built on an intimate-insider research providing an alternative perspective (Taylor, 2011). The aim of this study is to understand the way academic teachers dealt with the sudden shift in teaching practices during COVID-19 and the challenges accompanying such shifts. This paper addresses this issue by examining the following research questions:

1. What were the pedagogical and didactic challenges the academics faced while trying to adjust their teaching to the conditions created by COVID-19?

2. How did the alterations made in response to the pandemic impact the teacher-student interactions?

3. What are the implications of COVID-19 for academic teaching in the near future?

In order to answer these research questions the study relies on the experiences of three academics at the School of Social Sciences at UI during COVID-19. These academics were at the time attending the UI postgraduate diploma of Teaching Studies for Higher Education. For the sake of clarity, the paper is organized into four main sections. The next section consists of the theoretical background of this research, after which the methodology is presented. The findings section contains the three key themes of the study. The final section discusses the lessons learned along with an outline for future research and concluding remarks.

\section{Theoretical background}

In this section, we provide the theoretical insights on which we build this study. We focus on the challenges of online teaching, digital course assessments and moving towards a more student-centred learning approach. While the latter is believed to be more beneficial to the students' learning process, it often requires teachers to take on the role of a reflective practitioner and reconsider previous teaching practices (Schön, 1983).

\section{Moving teaching online}

In his announcement to students on March 16th, the UI Rector wrote:

Many aspects of teaching at the University are already digital, e.g. lectures, communication between students and teachers, discussions, assignment submission, assessment and more. Teachers and other University staff will endeavour to introduce you to digital solutions over the next days and weeks and implement new solutions where necessary, not least concerning assessment and final examinations [...] This is a huge challenge that the University is well prepared to face.

While the Rector was trying to reassure the students, the demand for flexibility and technological advancements in higher education (Kukulska-Hulme, 2012) was there well before COVID-19. It had already been claimed that higher education institutions needed to respond to technological development by providing more online learning, online content, and more effective tools to support more flexible learning experiences for students (Educause, 2020). The COVID-19 pandemic, however, threw these demands into rapids. 
Technological developments have made it much easier for teachers and students to interact online in real time (Boettcher \& Conrad, 2016). Nevertheless, transforming on-campus teaching to online teaching requires professional development and technical support and assistance in adjusting teaching material (Kebritchi et al., 2017). Teachers must juggle administrative roles (the organization of course material), with pedagogical (teaching methods), social (communication and caring), and technological roles (technical support) (Juan et al., 2011).

Under normal circumstances academic teachers use months to carefully plan and develop the pedagogy of a fully distant learning course in order to ensure its quality (Sigurgeirsdóttir \& Jóhannesdóttir, 2020). The focus of this study is, however, on what Hodges et al. (2020) refer to as Emergency Remote Teaching or online teaching that is characterised by an unprecedented and staggering speed.

Academic institutions have invested in Information and Communication Technology (ICT) in the past three decades to support distance learning and more flexible ways of teaching and learning (Kirkup \& Kirkwood, 2005). Prior to the pandemic ICTs predominantly played a supporting role rather than leading to radical new learning practices (Haynes et al., 2004; Kirkup \& Kirkwood, 2005). COVID-19 has also crystallized that planned digital online teaching and emergency remote teaching (Hodges et al., 2020) are not interchangeable but in fact two different teaching realities. Moreover, another difficulty highlighted by COVID-19 relates to Lloyd (2009) and his claim that technology blurs the boundaries between work and private space as one can be reached anywhere and under any circumstances due to online working arrangements. While the arrangements offer flexibility they also come with a demand for constant availability (Byström et al., 2019) especially when it is known that travelling is kept to a bare minimum and people are encouraged by their governments to stay at home.

Several domestic reports have been made on online teaching. Geirsdóttir et al. (2007) drafted a distant-teaching policy for UI and Pórsteinsdóttir et al. (2007) studied how Icelandic universities organize their distant teaching. The results of these studies show a lack of common policy and clear responsibility for further development and cooperation between different universities and faculties. The results also show that advances in the use of digital tools have mainly been carried out by enthusiastic teachers rather than as a top-down requirement (Pórsteinsdóttir et al., 2007). Online teaching has, for instance, been offered by individual faculties and more holistically at program level at the UI School of Education (Hafsteinsson et al., 2013; Jóhannsdóttir \& Jakobsdóttir, 2010). In recent research on teachers' readiness to transform their teaching to online teaching during COVID-19 Guðmundsdóttir and Hathaway (2020) used a four-dimensional model titled PEAT as an analytical tool to categorize teachers' attributes and capacity for teaching online. The dimensions underlying the model are pedagogical (pedagogical knowledge and skills), ethical (online responsibility, critical use of resources and plagiarism), attitudinal (teachers' agentic stance when using technology) and technical (ability to knowledgeable use of software and hardware). Guðmundsdóttir and Hathaway's findings indicated that teachers had positive attitudes towards the challenge of teaching online while focusing more on the technical aspect of online teaching than on the pedagogical aspects with little focus on the ethical dimension of online teaching. Although the teachers in Guðmundsdóttir and Hathaway's (2020) study are teaching at lower school levels, their findings and the analytical model used in the study are a helpful tool in examining the experiences of academic teachers during times of crisis.

\section{Course assessment}

One of the most challenging tasks of moving to online teaching relates to changes in assessment and final examinations (Stödberg, 2012). At UI, assessment practices vary between disciplines and schools (Reglur fyrir Háskóla Íslands nr. 569/2009). The recent policy of the UI on Quality in Teaching and Learning 2018-2021 emphasizes the role of feedback, which is framed within a wider attempt to encourage more formative assessment (Háskóli Íslands, 2018). Assessment practices still lean heavily towards final examinations, where issues of plagiarism are of significant concern (Stuhmcke et al., 2016). 
Assessment practices within higher education have, in recent decades, become an area of special interest for higher education researchers and developers. Emphasis on learning outcomes, diversity in learning activities, and student-centred approaches have called for assessment practices to evolve (Boud \& Falchikov, 2007; Carless, 2015). Due to the centrality of assessment in teaching and learning and its significant influence on the student experience, authors like Boud et al. (2009) have suggested that it is the most significant area for improving the quality of learning.

Nevertheless, changing assessment practices is difficult and such attempts often meet with resistance among teachers (Deneen \& Boud, 2014). There are many reasons for teachers' resistance to changing their assessment practices. Those practices are often tightly embedded in disciplinary cultures (Postareff et al., 2012; Yeo \& Boman, 2019) they are seen as a part of institutional quality assurance and accountability, they greatly influence students' learning behaviours and they often reveal the power unbalance between students and teachers (Mann, 2008; Weimer, 2002).

\section{Student-teacher interaction}

Aside from moving teaching online and redesigning assessment and examination practices, academic teachers were expected to be sensitive to students' needs and feelings due to the pandemic. Studentteacher interaction is an intricate issue. Using a symbolic-interactionist approach to analyse the relations between students and teachers, Ashwin (2012) stresses the complexity of the interactions because of the role teachers see themselves in, teacher identity, students' identity, disciplinary practices and traditions, and institutional culture. Student-teacher interactions are not stable and students and academics may perceive that different positions are available to them depending on their 'teaching' or 'learning' careers, their personal identities, the learning-teaching environment and the disciplinary and institutional settings of the interactions (p. 82).

Various attempts have been made to explore teachers' different pedagogical approaches towards their teaching. Originating alongside research on students' approaches to learning (Entwistle \& McCune, 2004; Marton \& Booth, 1997) a growing body of research has focused on teachers' approaches to teaching and the connection between those approaches and specific conceptions of teaching. Most studies categorise teachers' approaches as either teacher-centred or student-centred. Teacher-centred teachers frame teaching mainly within the process of transmission of knowledge, while those holding a student-centred approach see teaching as a tool to facilitate student learning or support students' conceptual changes (Biggs, 1999; Kember \& Kwan, 2002; Prosser et al., 1999; Samuelowicz \& Bain, 2001).

Researchers do not agree on the stability of teachers' approaches to teaching. Kember and Kwan (2002), for example, see them as relatively stable and argue that changing teachers' beliefs requires great effort. Other researchers emphasize both the dynamic nature of the approaches and their contextual sensitivity (Lindblom-Ylänne et al., 2006; Prosser et al., 1999). They argue that conceptual changes can occur as teachers gain experience in teaching (Kugel, 1993) or from changes in the institutional context of teaching (Samuelowicz \& Bain, 2001).

In recent decades, higher education discourse and policy have stressed the need for more studentcentred approaches in teaching and learning; something that is emphasized even more by the reliance on online teaching during the COVID-19 pandemic. Those discourses have also been related to neoliberal influences such as the marketization of higher education (White, 2017) and to humanistic educational approaches (Weimer, 2002). Student-centred teaching and learner-centred teaching stress the need for increased student agency and engagement in the learning process. They emphasize openness, inclusiveness, and support of students, which result from institutional practices and from meeting students with care and kindness in the classroom (Clegg \& Rowland, 2010; Mann, 2008). Advocates for learner-centred approaches also claim that the move from teacher-centred to student-centred approaches requires redistributing the balance of power in the student-teacher relation, emphasizing more cooperative relations between students and teachers and thus changing the traditional role of the teacher and levelling out traditional hierarchies (Klemenčič, 2021; Mann, 2008; Weimer, 2002). 


\section{Teachers' professional development}

Requirements for teaching competence and more scholarly practices in teaching have been embedded into policies, professional frameworks, leadership responsibilities, and quality systems (Gibbs, 2013; Stensaker et al., 2017). To meet the demand for increased professionalization in teaching, various forms of academic development services and activities have been established within higher education institutions. While the structure and focus of academic development offerings may vary between institutions (Bamber et al., 2009), the reflective practitioner is the major model for continuing professional development at the micro level (Ashwin et al., 2015). The idea of the reflective practitioner refers to a process where practitioners reflect and learn from their own experiences in order to develop their pedagogical ideas and approaches (Schön, 1983). Both formal and informal activities can promote professional learning (Van Waes et al., 2016). Reflections on teaching can take place informally in, for example, what Roxå and Mårtensson (2009) refer to as significant conversations within significant networks, where teachers have private discussions with a small group of colleagues that provide the foundation for conceptual development and learning. Such networks provide the space for a dialogue that is the prerequisite for development and change (Elmgren \& Henriksson, 2014). Significant conversations can provide participants with new ideas, inform their understanding of teaching, and be a place where professional and emotional support is offered (Pataraia et al., 2014; Rienties \& Hosein, 2015). Handal (1999) claims that due to university teachers' lack of formal teacher training, constructive and critical dialogue on teaching and learning is an essential part of increased professionalism in teaching. To engage in a meaningful dialogue, teachers need to be able to analytically and critically review their teaching practices, preferably with a critical friend, defined as "a person whose views you care about and (may) listen to and follow" (Handal, 1999, p. 8). As critical friends the teachers are able to share anxieties and enthusiasm about their positions as teachers and the challenges, difficulties and strategies they encounter. Such conversations are often formally introduced within pedagogical courses for academics to promote criticality of current practices and develop teachers' conceptions of teaching (Brookfield, 1995) and have been found to be successful (Rodgers et al., 2014).

\section{Methodology}

The data for the study derive from the experiences of three academics in Social Sciences who were at the time participating in a post-graduate diploma on higher education at UI. They were, therefore, in the unprecedented role of simultaneously teaching and learning during COVID-19. The course the academics were attending is titled Assessment and Feedback. Its aim was to facilitate academic teachers' critical reflection on their own courses. Due to the pandemic the second part of the course was taught online and the course assessment was adjusted with the option of writing about teaching experiences at times of COVID-19. The role of the supervisor of the course, and fourth author of this paper, was to act as a facilitator and to introduce structures to support the professional learning processes of the three academic teachers. Thus, all four authors were involved in an emergency remote teaching learning process during the spring semester of 2020 (Hodges et al., 2020) as individual teachers and, for the three academics, also as students in the post-graduate diploma.

In a previous course towards this diploma, the three teachers had been working on an approach related to a model called lesson study (Cerbin \& Kopp, 2006; Watanabe, 2002) which entails participant observation followed by collegial discussions (also, Donelly, 2007). Herein, the significant network of the three academics was first created. The approach proved successful and the academics all felt that they gained from it. Not only was it very effective in terms of enhancing reflectivity, awareness and comparison, it also brought positive emotional results by providing a free and safe space which permitted these colleagues to act as critical friends. A characteristic of a critical friend is, on the one hand, a friendship built on trust and support and, on the other, peer criticism based on analysis and assessment and shared personal reflections (Handal, 1999; Wennergren, 2016). 
The primary data for this study derive from Q\&A which was part of the course assessment in the post-graduate diploma, personal notes and reflections of the three academic teachers participating in the post-graduate diploma as well as shadowing logs produced while conducting classroom observations. The Q\&A entailed a face-to-face session with the three academic teachers taking rotating roles of interviewer, respondent and amanuensis. The interview framework consisted of the following common set of questions, which revolved around the changes that had been implemented during the emergency remote teaching. More specifically we asked: In what manner was the teaching and assessment altered due to COVID-19? What technology and tools were used for teaching and interaction with students? What changes were implemented and how did the students react? What proved to be successful and what were the hiccups and drawbacks? What is the lesson to be learned that could affect future teaching? The answers were, therefore, built on the personal experiences of the teachers and their understanding of the student experience as it emerged from their interactions during online teaching and frequent email communication. The notes of these interviews were then shared, and alterations were made by individuals reflecting on their own text. These questions were further elaborated and probed upon by the academics themselves functioning as critical friends. They took notes and applied their learning to their courses while supported by each other and their supervisor. In this paper, the three academics and their supervisor reflect more extensively on these notes, barely half a year later. The notes were analysed individually by means of thematic analysis (Creswell, 2013) and discussed in group sessions in which the three teachers and the supervisor took part.

Secondary materials considered in this study are interactions and e-mails from students, the midterm student evaluations (SET), which the teachers interpreted in light of their personal knowledge of the student population and the course, and emails sent by the Rector of UI during the spring semester 2020. These emails were sent in order to keep academic staff and students informed on the impact of the pandemic within the university. The emails were sent between February 27 and April 30 and are available on the UI website.

\section{The courses}

The teaching contexts of the three teachers varied. The student number and the courses differed quantitatively with a larger number of students in sociology and fewer in anthropology and information science. The geographical location of the students also differed in accordance with the percentages of registered distant students. In anthropology many students were living abroad, even in other continents. Finally, there were differences in the students' living conditions which emerged during online teaching and interactions. An overview of the course demographics is presented in Table 1.

Table 1. Course demographics

\begin{tabular}{lllll}
\hline Department & Course size & Students' age range & Program level & $\begin{array}{l}\text { Distance learning } \\
\text { students }\end{array}$ \\
\hline Sociology & 120 & $22-52$ & undergraduate & $0 \%$ \\
\hline Anthropology & 24 & $27-70$ & $\begin{array}{l}\text { graduate and } \\
\text { undergraduate }\end{array}$ & $40 \%$ \\
\hline Information Science & 14 & $28-61$ & graduate & $60 \%$ \\
\hline
\end{tabular}

Another difference was the amount of experience the three academics had in online teaching. In the sociology department, online teaching did not form part of teaching practices before the pandemic; while in information science, simultaneous online and on-campus teaching had been practised for years. Anthropology was situated somewhere in the middle, having the option of online learning, but with an emphasis on maintaining the bulk of teaching activities and communication on-campus. 
Distant anthropology students formed almost half of the student population but the teaching methods were not much constructed around their needs. Students could access recorded lectures and participate in discussion boards via an online forum.

Another difference concerned assignments. In the case of the anthropology course, being strongly focused on in-class activities, attendance and participation carried much weight in the course assessment. The assessment was based on weekly short memos, a final essay and an in-class workshop or online forum for distance students. In information science, all students were expected to participate in three on-campus modules. Also, part of the assessment was a group project in which students would visit different organizations, conduct interviews and perform an evaluation. In the sociology course, there was a strong emphasis on preparing students for the final written exam. Two group assignments, two research reports based on SPSS analyses, formed the remainder of the course assessment.

\section{The participants}

The three academic teachers participating in the post-graduate diploma share some common ground. They are all relatively young teachers within the School of Social Sciences, each with around a decade of teaching experience. In the spring of 2020, each of them was expected to autonomously make decisions about the courses they were teaching and, thus, freely elaborate and implement changes in terms of teaching activities, assignments, deadlines, and interaction/communication with the students. Within this common ground, there are also differences between the three teachers. They are engaged in different disciplines within the multifaceted worlds of Social Sciences and are part of different faculties.

The fourth participant of this study, the supervisory facilitator, had a dual role as well. As a teacher in the Assessment and Feedback course she faced pedagogical challenges of altering her teaching practices. As an academic developer she was supporting a group of teachers (15 in total) from different schools and faculties of UI in their efforts to change their teaching strategies due to the pandemic. Her role in this study is, therefore, both participatory and pedagogical.

It is worth mentioning that when working on the collective project for the Assessment and Feedback course and when rereading the notes for this paper, a series of general themes and reflections appeared as uniting the four authors despite the differences listed above. The intertwining of commonality and shared experiences during the COVID-19 outbreak with the specificity of each individual teacher, their affiliations, and the courses they taught created a stimulating environment for sharing common ground, challenges and the different approaches and solutions adopted to cope with various impacts of COVID-19.

\section{Ethical issues and the limitations of this study}

From the beginning of this research it was clear that the setting was going to be both a strength and a limitation. This research was conducted at the UI by three teachers studying their own personal courses and individual ways of coping with the impacts of COVID-19 on their teaching practices. The small number of courses being studied and the social network of the three teachers helped in the research process.

Familiarity with the research topic is an advantage as it may help to have former knowledge of the circumstances being studied. Nevertheless, in an intimate-insider research as done in this study, the researchers need to be reflective in taking their own beliefs, experiences and values into account (Esterberg, 2002; Taylor, 2011). The position of the researchers in relation to COVID-19 responses within different departments, courses and among the courses under study may have impacted the research process and the analytic stance (Berger, 2015). In qualitative research the researchers become tools in the research process (Creswell, 2013; Jóhannesson, 2006). While the researchers may have an 
opinion on the subject being studied, or even some idea of the right answers to their own questions, writing notes, repeatedly reviewing the data gathering and analysis and seeking peer consultation helps correct biases. The use of a critical friend as a method for this study adds to the validity of the analysis. It is also helpful for the validity of the research to obtain distance from the data and analysis for a while and return back some time later after the original analysis as done in this study.

Anonymity protects the identity of individuals or settings from being known (Esterberg, 2002). Even if the courses that are part of the data collected for this study may be related to the authors of this paper, it was considered appropriate not to name individual courses and to protect the student population by not revealing their particular age, sex or residence. They are referred to as a group of students of a certain age range within each course, of which a certain percentage is registered as distance students.

\section{Findings}

Moving to online teaching requires a series of adjustments regarding technical, attitudinal, pedagogical and ethical aspects of teaching (Guðmundsdóttir \& Hathaway, 2020). Transforming on-campus teaching into online teaching meant getting familiar with new computer programs and learning platforms such as Canvas Studio, Zoom, Teams, and Inspera. Not all of these platforms were completely unknown to the teachers. Sharing personal knowledge and experience about new programs and platforms with the critical friends (Handal, 1999; Wennergren, 2016) reduced the difficulties that many academic teachers encountered due to the pandemic when implementing adjustments without proper training and support (Kebritchi et al., 2017).

Panopto was already well integrated into the teaching system and the academic teachers had previous experience using it. Up to this point, Panopto had mainly been used as a supportive tool to record on-campus course sessions (Kirkup \& Kirkwood, 2005). Using Panopto in a different mode when recording at home had its limitations which pushed the teachers to switch to alternative platforms. The experience with Canvas Studio revealed itself quite successful. This newly introduced system was considered much more user-friendly than Panopto. It gave the teachers the perception of having more agency in their teaching, fostering flexibility and creativity (Guðmundsdóttir \& Hathaway, 2020). Instead of giving distant students access to captured classroom recordings, all students had the same access to predefined short recordings with a specific focus. In the student evaluations (SET) students expressed their appreciation of the new format as they could then choose certain themes from the study material and organize their time better.

One of the unexpected positive sides of teaching online was the fact that the boundaries of time and location were more flexible. This contributed to a more equal participation between distant and oncampus students. Distance students became more visible and were able to participate in the lessons to a fuller extent than before. Now they claimed a spot in Zoom or Teams meetings, one exactly as large as the others on the screen, which meant that they could enjoy the teaching experience at the same level and were more included and actively involved than ever before.

Teaching through Zoom or Teams required additional organisation as these were new platforms for instruction. This often resulted in inventiveness to compensate for lack of familiarity. The teachers had to learn and familiarize themselves with these programs. Among the experiments carried out on Teams was when one of the teachers invited a guest lecturer to participate in a two-person meeting. This was the first formal teaching experience of the guest lecturer, so they decided not to invite the students to participate in the meeting but to record it and then share it on the student platform. This example suggests that it would have been preferable to invite students to participate in the online meeting in order to boost the discussion between students and the lecturer. In another instance one of the teachers planned to watch a 54-minute movie using Zoom with the intention of discussing the movie afterwards. This teacher did not know how to share the audio through the share screen mode. Instead of throwing in the towel the teacher opted for a quick escamotage and used two 
computer screens, broadcasting the movie on one and sharing it with the students via webcam. The class watched the whole movie and the discussion afterwards was deemed successful in the teacherstudent interactions.

Still, the three teachers all missed the physical presence of the students in class and the instant feedback and eye-contact with students. This was partly compensated for by using Zoom or Teams which enabled direct communication between teachers and students. The teachers found it easier to communicate their course material to the students and were happier to interact with an audience, while the students appreciated the visual contact and interaction with fellow students and their teachers. When asked during online discussion in class whether the students preferred online teaching over on-campus teaching, many of the on-campus students revealed that they missed the in-class interactions, that they were tired of being at home, and that their student apartments seemed to be getting smaller every day. According to the students, on-campus teaching could not easily be replaced but they seemed to realise that there was little to be done about COVID-19 and seemed grateful for getting any kind of instruction. This is in line with the findings of Björnsdóttir \& Jóhannsdóttir (2020) where the majority of students at UI appreciated the teachers' efforts to redesign their courses.

One of the pedagogical challenges was to organize and carry out effective interaction and discussions using Zoom and Teams. This proved to be even more demanding than on-campus teaching. There was a tendency for a small group of students to dominate the conversation by continuously asking questions, while others chose to stay invisible, preferring to just listen in instead of actively participating. All three teachers offered the students the opportunity to request personal Zoom or Teams conversations, but this option was only occasionally used. Thus, while supporting the findings that the distance between teacher and student decreases through the digital format of the teaching (e.g., Boettcher \& Conrad, 2016), our experience also highlights a more complex situation. Individual students were still quite reluctant to contact the teacher in person; instead, requesting a meeting with a small group of students at the same time was more popular, and both teachers and students experienced these small digital group sessions to be fruitful and enjoyable.

\section{Rethinking assessment in the eye of the storm}

Following the Rector's instructions in an email on March 31 all three teachers tried to uphold the original course assessment as well as they could because they believed that drastic changes in this context would increase feelings of insecurity among the students. While initially they were considering the possibility of reducing feedback on assignments to lighten the teaching workload, the teachers realized that this was not a viable option as the students appeared to need more encouragement than usual. They also decided to revise their assessment guidelines by extending deadlines and granting further extensions when those deadlines could not be met. This shift in teachers' attitudes towards a more student-centred approach in teaching (e.g., Biggs, 1999; Kember \& Kwan, 2002) was generally experienced as helpful by the students, some of whom had difficulties in making the deadlines as their private lives were also calling for reorganisation and adjustment. The actions taken included lowering the requirements concerning the quality of assignments, prioritizing formative assessment to help students complete the course and providing more positive and encouraging feedback than they would have received under normal circumstances.

In the sociology course the assignments were simplified as an outreach to the students. Nevertheless, not all students appreciated the adjustments or experienced them as beneficial. In their correspondence to the teacher, several students signalled that the adjusted assignment was "really difficult" and not "what they were used to". This may indicate that the students felt insecure and were clinging onto the stability of their studies. Other attempts to change assessments, as in information science, turned out to be more successful. Usual on-site visits or on-campus activities were transformed to online teaching or other forms of digital interactions. The quality of the students' reports exceeded the expectations of the teacher. However, despite the extraordinary efforts of the students in information science, on-site contacts and the teacher, it was hard to get around the fact that the visual aspects of the experience were missing. 
More interruptive and defining for the course assessments, however, was the Rector's announcement on the 23rd of March, installing a new set of rules regarding final examinations. This was done to "eliminate the uncertainty that [might] be a source of stress to the students". One of the adjustments was that specific faculty rules requiring students to achieve a minimum grade in the final exam and course projects did not apply in the 2020 spring semester and the weighted average grade for all course components was accepted as the final grade. This rule also applied to examinations retaken from the fall 2019 semester. The fact that a minimum grade of 5.0 for each course component was no longer required meant that the student achievement of the learning outcomes could no longer be ensured in some cases. Students who, under normal circumstances, would not have passed the course requirements, did so during COVID-19 despite weak or failing grades. Students who used 50\% additional exam time or more or blamed the Inspera program for not shutting down on them. Such developments left the teachers slightly disillusioned regarding final examinations and raised ethical questions regarding the reliability and validity of the assessment (Guðmundsdóttir \& Hathaway, 2020). Nevertheless, the vast majority of students did very well in the examinations which undeniably was a positive general outcome.

\section{We are all in this together: Interacting with care}

The pandemic increased the amount of emails and influenced the way teachers and students communicated and related to each other. The Rector set the tone in the beginning of March by asking the staff and students to "look out for one another, encourage people to go home if they appear to be ill, and take particular care to look out for people who have no support network in Iceland". The teachers responded with a similar tone in their announcements and increased online communication with the students. The interactions were, therefore, more receptive to students' needs (Clegg \& Rowland, 2010) and demonstrated a caring approach that emphasized the well-being of the students and their families. Announcements were often opened with sentences such as "Now that we have survived our first COVID weeks, I hope you and your family are doing well", and/or concluded with the invitation to "stay healthy and take good care of yourselves and your loved ones". The students replicated this friendlier and more personal tone in their interactions with the teachers.

The three teachers found themselves in a position between a rock and a hard place. They felt responsible for the well-being of the students and their successful completion of the courses. However, this was sometimes at the expense of their own well-being. This ambivalent situation was recognized by the Rector in a message from March 27th.

Now the weekend is almost here and many of us will be able to relax with our loved ones. Nevertheless, many will still be hard at work and some are dealing with anxiety. It is important to ask for support, as well as supporting those who are closest to you. We must look out for one another and remember that our mental wellbeing is essential if we are to weather this storm. Let us also not forget that these times will pass. We must stand united and together we will prevail.

The feeling of loneliness and the anxiety related to health risks and isolation in lockdown was a shared teaching and learning experience. Acting as critical friends helped the three teachers cope with the challenges they encountered (Handal, 1999). They strived to endure what they considered a temporary situation by applying Emergency Remote Teaching (Hodges et al., 2020) in an attempt to finish their courses without failing the students. This overall situation triggered stress, but created closer proximity and partly lowered the hierarchies characterizing the university environment, both between students and teachers and between distant and on-campus students (Klemenčič, 2021; Weimer, 2002). As highlighted by previous research (e.g., Byström et al. 2019; Loyd, 2009) ICTs blurred the separation between public and private space and roles. While on-campus lectures and online discussion forums allowed students and teachers to maintain a strategic presentation of the self (Goffman, 1959), Teams and Zoom opened a window into the intimate space of their homes. The personal life of individuals that had previously been kept at a safe distance from the eyes of outsiders was all at once exposed to their gazes. 


\section{Discussion and conclusion}

In this paper, we set out to shed light on the way academic teachers dealt with the sudden shift in teaching practices during COVID-19 and the challenges accompanying such shifts.

The first research question addressed the pedagogical and didactic challenges the academics faced while trying to adjust their teaching to the conditions created by COVID-19. The findings revealed that the experience was similar to what Guðmundsdóttir and Hathaway (2020) discovered in the sense that the teachers did not find it too difficult to deal with the technological aspect of online teaching. The three teachers were pushed out of their comfort zone in terms of the use of technology, which under normal circumstances had been mainly used as a supportive tool to record on-campus course sessions (Kirkup \& Kirkwood, 2005). Experimentation with alternative platforms and didactic methods gave the teachers the perception of having more agency in their teaching, fostering flexibility and creativity (Guðmundsdóttir \& Hathaway, 2020) needed to cope with this emergency situation.

Differently from the findings of Guðmundsdóttir and Hathaway (2020), however, our study highlights how, in the switch to online teaching, the teachers also focused on pedagogical aspects and on the ethical dimension. From the pedagogical perspective, the changes were quite challenging and can best be described as attempts to quickly move on-campus designs to an online format, without the planning and development necessary to ensure the quality of a distance learning course (Sigurgeirsdóttir \& Jóhannesdóttir, 2020). Thus, this kind of emergency remote teaching (Hodges et al., 2020) bears little resemblance to carefully planned course design in online teaching (Jóhannsdóttir \& Jakobsdóttir, 2010). The teachers' attempts to redesign teaching and assessment proved to be only partly successful, although students in general showed appreciation and understanding of the situation (Björnsdóttir \& Jóhannsdóttir, 2020). There were victories but also mistakes and hiccups due to the lack of time and planning. This demonstrates the need for pedagogically sound methods in curriculum design. The question is then whether and to which degree all on-campus teaching activities can be organised online (Geirsdóttir et al., 2007; Hafsteinsson et al., 2013). The study highlights that on-campus in-class activities and the physical, embodied dimension of the teaching/ learning experience cannot and should not be fully replaced. There is some added value in what a student jokingly called the "world of the flesh" (kjötheimur in Icelandic), referring to the physical world with the presence of people in the flesh that no technology can reproduce yet.

In their attempts to respond to the Rector's requirements, the three teachers implemented changes in their assessment practices. Some of these changes raised ethical questions (Guðmundsdóttir \& Hathaway, 2020) and challenges (Deneen \& Boud, 2014; Stödberg, 2012) as the teachers felt that the quality of certain aspects of the courses could no longer be ensured. At the same time, the need for more formative and encouraging feedback was met by the teachers by leaning towards more studentcentred practices (Boud \& Falchikov, 2007; Carless, 2015).

This angle connects to the second research question, which revolves around the impact of COVID-19 on the teacher-student interactions. The findings reveal that as the teachers became learners trying to manage new methods and technologies, their authoritative stance decreased. This enhanced student participation and the understanding of teacher efforts increased (Björnsdóttir \& Jóhannsdóttir, 2020). It also made teachers more sensitive to students' circumstances and more responsive to their needs. This process was further intensified by the use of technology as Teams and Zoom opened up a window into the intimate space of both students and teachers. As a result, the relationship between distance learner students, on-campus students and teachers changed. Previously, teaching methods had not been much constructed around distance student needs but rather maintained the distance students at the margins of the courses. The switch to an exclusively online mode of teaching produced more equal participation between distance and on-campus students. Also, the findings show that the experience of COVID-19 affected student-teacher relations. The teachers moved towards more student-centred approaches which, in turn, increased students' agency (Klemenčič, 2021; Mann, 
2008; Weimer, 2002). Despite Kember and Kwan's claim (2002) on the stability of teachers' beliefs, it is apparent that the context the teachers found themselves in, influenced their perceptions of their students (Lindblom-Ylänne et al., 2006; Prosser et al., 1999; Samuelowicz \& Bain, 2001). This also affected their practices, which became more caring and attuned to students' needs at the same time as the power unbalance between teachers and students (Klemenčič, 2021) became less pronounced than before.

Finally, the third research question concerned possible implications of COVID-19 for academic teaching in the near future. The challenges described above, on the one hand, have to do with the teachers' struggle with technology and pedagogy in emergency situations, and on the other, with how that experience influenced their approaches to and perceptions of students. There are some lessons to be learned from this situation that can be implemented into future teaching. Firstly, there are clear benefits from using technology to improve the quality of teaching and, thus, the students' learning experience. However, if teachers are to continue this experimentation, as suggested by Gunnarsdóttir \& Pálsdóttir (2020), institutions need to strategically support this endeavour in the long term. Secondly, COVID-19 triggered a further move toward a student-centred approach. This approach represented a resource for figuring out emergency solutions. It also appears as the appropriate lens through which academics should develop their future teaching practices, at least in reference to distance teaching and distance students. Thus, the study shows that the pandemic triggered unforeseen results regarding more general changes in the pedagogy used in the courses with a switch to a more flexible teaching approach, both in terms of adaptability to sudden changes and in terms of receptivity to the needs of students (Clegg \& Rowland, 2010; Mann, 2008). This flexibility is likely to remain once the pandemic has been defeated. So far, the lessons learned have already been useful for the fall semester of 2020 and in preparation for teaching and didactics for the spring semester of 2021. The difference from the experience of the spring 2020 semester is that this approach no longer qualifies as emergency teaching but resembles the more carefully planned pedagogy of a fully distant learning course (Sigurgeirsdóttir and Jóhannesdóttir, 2020).

To conclude, despite a steep learning curve, the teachers' experiences presented in the study show that difficulties can bring about anxiety, but they can also be a drive towards improvement and development for teachers. Our experiences of coping with the challenges of COVID-19 have demonstrated the importance of belonging to a significant network, a group in which reflective conversations are carried out and emotional support provided. This form of professional development should be encouraged and supported within the academic environment.

\section{Acknowledgements}

We are using a multiple first authors practice in this study. All authors have contributed equally to the design of the study, the data collection and analysis and the writing process. The authors are grateful to the reviewers for their insightful comments and useful remarks. 


\section{Á fleygiferð upp bratta lærdómskúrfu: Reynsla háskólakennara af breytingum á kennslu og námsmati á tímum COVID-19}

Í lok febrúar 2020 lýsti ríkislögreglustjóri, í samráði við sóttvarnalækni og landlækni, yfir óvissustigi almannavarna vegna COVID-19. Rektor Háskóla Íslands hvatti starfsfólk og nemendur til að fylgjast með upplýsingum frá Landlæknisembættinu og hlýða ráðum og fyrirmælum sem paðan komu. Í kjölfarið var neyðarstig almannavarna virkjað á Íslandi og samkomur takmarkaðar til að vernda íbúa landsins. Um miðjan mars var háskólum lokað og fengu kennarar Háskóla Íslands pað verkefni að færa alla kennslu á örskömmum tíma úr hefðbundnu staðnámi í kennslustofum yfir í fjarnám. Háskólakennarar bjuggu á pessum tímapunkti yfir mismikilli reynslu af rafrænum kennsluháttum og margir peirra hófu hraða vegferð upp bratta lærdómskúrfu. Á meðan rannsóknir hafa beinst að upplifun og reynslu nemenda, líðan peirra og atvinnuhorfum á tímum heimsfaraldurs, hafa fáar rannsóknir varpað ljósi á leiðir kennara á háskólastigi til að endurskoða og aðlaga eigin kennslu og samskipti við nemendur að breyttri tilveru. Pessari rannsókn er ætlað að veita innsýn í reynslu háskólakennara af skyndilegum breytingum á kennsluháttum á tímum COVID-19.

Markmið pessarar greinar er að varpa ljósi á úrræði priggja háskólakennara sem höfðu pá sérstöðu að vera samtímis í hlutverki kennara og nemenda á pessum fordæmalausu tímum. Sem kennarar báru peir ábyrgð á að mæta farsællega peim áskorunum sem óhjákvæmilega fylgdu heimsfaraldrinum fyrir nemendur, og vörðuðu námsmat, endurgjöf og prófafyrirkomulag. Sem nemendur stunduðu kennararnir nám í háskólakennslufræði og upplifðu pví á eigin skinni hvernig námsfyrirkomulag færðist milli stað- og fjarnáms með litlum fyrirvara. Í greininni er lögð áhersla á pá pætti sem snúa að rafrænum kennsluháttum, námsmati, samskiptum kennara og nemenda og lærdómi kennara af ofangreindum páttum.

Rannsóknargögn samanstanda af ígrundun kennarana á eigin úrræðum í kennslu sem unnin var í námskeiðinu Námsmat og endurgjöf á vormisseri 2020, reynslu peirra af að fylgjast með kennslu hver hjá öðrum, kennslumati námskeiða, samskiptum við nemendur sem og tilkynningum og fyrirmælum háskólarektors til starfsfólks og nemenda á tímum COVID-19. Aðferðir priggja kennara í pessari rannsókn fólust ekki síst í að vera gagnrýninn vinur (e. critical friend) í samstarfshópi (e. significant network) en pað er aðferð sem felur í sér að rýna saman kennsluhætti til gagns, skapa aðstæður fyrir traust og opin samskipti og veita stuðning í peim áskorunum sem felast í kennslu.

Niðurstöður benda til pess að á meðan markmið stjórnvalda hafi verið að „fletja út kúrfuna" til að hefta og hægja á útbreiðslu COVID-19, hafi markmið háskólans um að tryggja öryggi og velferð nemenda og starfsfólks og að nemendur gætu lokið námskeiðum með farsælum hætti orðið til pess að lærdómskúrfa háskólakennara varð brött. Pó kennararnir prír kenni innan sama fræðasviðs voru kennsluhættir peirra og skipulag námskeiða með ólíkum hætti. Breytingar á kennsluháttum, svo sem aukin og persónulegri samskipti við nemendur, tæknilegar áskoranir og endurskoðun námsmats, einkenndu pessa nýju kennsluhætti og juku vinnuálag kennara. Pannig fólst lærdómur kennara í að tileinka sér notkun ýmiss konar hugbúnaðar til að mæta kröfum um rafræna kennsluhætti. Peir purftu jafnframt að endurskipuleggja námskeið sín sem og námsmat. Kennarar stóðu einnig frammi fyrir að sinna mörgum og ólíkum hlutverkum samtímis, m.a. á sviði stjórnunar og kennslufræði, auk pess að fela í sér bæði félagslegan og tæknilegan stuðning við nemendur. Niðurstöður pessarar rannsóknar styðja fyrri rannsóknir hvað varðar pær áskoranir sem felast í að skipta stöðugt um hlutverk. Slík umskipti geta reynst kennurum erfið, ekki síst ef ekki hefur gefist tækifæri til pjálfunar áður en beita á nýjum aðferðum. Breytingar á kennsluháttum fólu einnig í sér jákvæðar hliðar, svo sem nýja reynslu kennara af upplýsingatækni, aukið jafnræði milli staðnema 
og fjarnema svo og nemendamiðaðri sýn kennara í kennslu. Niðurstöður benda einnig til pess að pátttaka kennara í háskólakennslufræði, áhersla námsins á ígrunduð vinnubrögð sem og náin samvinna og gagnkvæmur stuðningur á milli kennaranna priggja sem og milli peirra og leiðbeinanda námskeiðsins Námsmat og endurgjöf hafi orðið til pess að átökin við bratta lærdómskúrfu urðu viðráðanleg og hægt var í sameiningu að draga lærdóm af reynslunni.

Efnisorð: COVID-19, starfspróun, samskipti kennara og nemenda, rafrænir kennsluhættir, gagnrýninn vinur

\section{About the authors}

Guðrún Geirsdóttir (gudgeirs@hi.is) is an associate professor in education at the University of Iceland. She is also the director of the Center for Teaching and Learning. Her main fields of teaching and research relate to teaching and learning in higher education and professional development within higher education. She has a $\mathrm{PhD}$ in education from the Iceland University of Education; an M.Sc. in curriculum and instruction from Pennsylvania State University, a BA in pedagogy and a teacher certification from the University of Iceland.

Marco Solimene (mas18@hi.is) received his MA in sociology from the La Sapienza University in Rome, and holds a PhD in social anthropology from the University of Iceland. Since 1999 he has been conducting anthropological fieldwork among Roma communities in Italy, Romania and Bosnia, and has published works on movement and migration, memory, informality, governmentality and resistance. Marco teaches at the Department of Anthropology, University of Iceland.

Ragna Kemp Haraldsdóttir (rh@hi.is) is an assistant professor in information and records management and electronic communication in organizations at the University of Iceland. Her main field of teaching and research is on the human, communicative and organizational aspects of information management. She has a PhD in information science, a Cand.IT in information technology, communication and organizations from the University of Aarhus, and a BA in literature from the University of Iceland.

Thamar Melanie Heijstra (thamar@hi.is) is an associate professor in sociology at the Faculty of Sociology, Anthropology and Folkloristics at the University of Iceland. She has a PhD in sociology from the University of Iceland. Her main areas of expertise are organisational culture, work conditions, work-family balance, well-being and gender relations.

\section{Um höfunda}

Guðrún Geirsdóttir (gudgeirs@hi.is) er dósent í menntunarfræðum við Háskóla Íslands. Hún er jafnframt deildarstjóri Kennlsumiðstöðvar Háskóla Íslands. Rannsóknir hennar snúa að námskrárgerð, kennsluháttum og kennslupróun á háskólastigi. Guðrún er með doktorspróf í menntunarfræðum frá Kennaraháskóla Íslands, M.Sc. í námskrárfræðum frá Pennsylvania State University og BA gráðu í uppeldisfræðum auk kennsluréttinda frá frá Háskóla Íslands.

Marco Solimene (mas18@hi.is) er með meistarapróf í félagsfræði frá La Sapienza háskóla í Róm, og lauk doktorsgráðu í mannfræði frá Háskóla Íslands 2014. Frá 1999 hefur hann unnið að etnógrafískum mannfræðirannsóknum með Róma-fólki á Ítalíu, Rúmeníu og Bosníu. Rit hans fjalla um hreyfingu og innflytjendamál, minni, óformleika, stjórnunartækni og andóf. Marco er stundakennari við Mannfræðideild Háskóla Íslands. 
Ragna Kemp Haraldsdóttir (rh@hi.is) er lektor í upplýsingafræði með áherslu á upplýsinga- og skjalastjórn og rafræn samskipti við Háskóla Íslands. Í rannsóknum og kennslu hefur Ragna helst skoðað samverkan hins mannlega og hins tæknilega í stjórnun og miðlun upplýsinga. Ragna er með doktorspróf í upplýsingafræði, meistarapróf í stjórnun og miðlun upplýsinga frá Árósarháskóla og BA-gráðu í bókmenntafræði frá Háskóla Íslands.

Thamar Melanie Heijstra (thamar@hi.is) er dósent í félagsfræði við Félagsfræði-, mannfræði- og pjóðfræðideild Háskóla Íslands. Hún er með doktorsgráðu í félagsfræði frá Háskóla Îslands. Rannsóknir hennar og sérhæfing snúa að vinnumenningu, vinnuaðstæðum, samræmi vinnu og einkalífs, líðan og kynjajafnrétti.

\section{References}

Ashwin, P. (2012). Analysing teaching-learning interactions in higher education: Accounting for structure and agency (2nd ed.). Continuum International Publishing.

Ashwin, P., Boud, D., Coate, K., Hallett, F., Keane, E., Krause, K.-L., Leibowitz, B., MacLaren, I., McArthur, J., McCune, V., \& Tooher, M. (2015). Reflective teaching in higher education. Bloomsbury Academic.

Bamber, V., Trowler, P., Saunders, M., \& Knight, P. (2009). Enhancing learning, teaching, assessment and curri culum in higher education: Theory, cases, practices. Open University Press, McGraw-Hill Education.

Berger, R. (2015). Now I see it, now I don't: Researcher's position and reflexivity in qualitative research. Qualitative research, 15(2), 219-234. https://doi.org/10.1177/1468794112468475

Biggs, J. (1999). What the student does: Teaching for enhanced learning. Higher Education Research \& Development, 18(1), 57-75. https://doi.org/10.1080/0729436990180105

Björnsdóttir, A., \& Jóhannsdóttir, P. J. (2020). Viðhorf stúdenta til breytinga á námi og kennslu í HÍ vegna lokunar bygginga á vormisseri 2020 [Students' attitudes to altered study and teaching programmes at the University of Iceland, due to closures of school buildings in the spring semester]. Tímarit Kennslumiðstöðvar Háskóla Íslands, 8(1), 8-10. https://doi.org/10.33112/tk.8.1

Boettcher, J. V., \& Conrad, R. M. (2016). The online teaching survival guide: Simple and practical pedagogical tips. Jossey-Bass.

Boud, D., \& Falchikov, N. (2007). Rethinking assessment for higher education: Learning for the longer term. Routledge.

Boud, D., Sadler, R., Joughin, G., James, R., Freeman, M., Kift, S., \& Webb, G. (2009). Assessment 2020: Seven propositions for assessment reform in higher education. Australian Learning and Teaching Council. https://www. plymouth.ac.uk/uploads/production/document/path/2/2539/Assessment_2020_final_1_.pdf

Brookfield, S. (1995). Becoming a critically reflective teacher. Jossey Bass.

Byström, K., Heinström, J., \& Ruthven, I. (2019). Information at work; Information management in the workplace. Facet Publishing.

Carless, D. (2015). Excellence in university assessment. Routledge.

Cerbin, W., \& Kopp, B. (2006). Lesson study as a model for building pedagogical knowledge and improving teaching. International Journal of Teaching and Learning in Higher Education, 18(3), 250-257.

Clegg, S., \& Rowland, S. (2010). Kindness in pedagogical practice and academic life. British Journal of Sociology of Education, 31(6), 719-735. https://doi.org/10.1080/01425692.2010.515102

Creswell, J. W. (2013). Qualitative inquiry and research design: Choosing among five approaches (3rd ed.). Sage.

Deneen, C., \& Boud, D. (2014). Patterns of resistance in managing assessment change. Assessment \& Evaluation in Higher Education, 39(5), 577-591. https://doi.org/10.1080/02602938.2013.859654

Donelly, R. (2007). Perceived impact of peer observation of teaching in higher education. International Journal of Teaching and Learning in Higher Education, 19(2), 117-129. 
Educause. (2020). 2020 EDUCAUSE horizon report ${ }^{\mathrm{TM}}$ : Teaching and learning edition. https://library.educause. edu/-/media/files/library/2020/3/2020_horizon_report_pdf.pdf?la=en\&hash=08A92C17998E8113BCB 15DCA7BA1F467F303BA80

Elmgren, M., \& Henriksson, A.-S. (2014). Academic teaching. Studentlitteratur.

Entwistle, N., \& McCune, V. (2004). The conceptual bases of study strategy inventories. Educational Psychology Review, 16(4), 325-345. https://doi.org/10.1007/s10648-004-0003-0

Esterberg, K. G. (2002). Qualitative methods in social research. McGraw-Hill.

Geirsdóttir, G., Pálmadóttir, H., Ólafsson, R., Jakobsdóttir, S., Pálmason, P., \& Jóhannsdóttir, P. (2007). Mótun stefnu i fjarkennslumálum hins sameinaða háskóla - Lokaskýrsla verkefnishóps [Strategy formation in distance education matters relating to the merged university - a final report]. Kennaraháskóli Î́slands, Háskóli Íslands. http://hdl.handle.net/1946/17225

Gibbs, G. (2013). Reflections on the changing nature of education development. International Journal for Academic Development, 18(4), 4-14. https://doi.org/10.1080/1360144X.2013.751691

Goffman, E. (1959). The presentation of self in everyday life. Doubleday.

Guðmundsdóttir, G. B., \& Hathaway, D. (2020). "We always make it work": Teacher agency in the time of crisis. Journal of Teaching and Teacher Education, 28(2), 239-250. Retrieved from: https://www.learntechlib. $\mathrm{org} / \mathrm{primary} / \mathrm{p} / 216242 /$

Gunnarsdóttir, E. D., \& Pálsdóttir, K. Р. (2020). Áhrif COVID-19 á störfog vinnuaðsteður starfsfólks Háskóla Islands [The impact of COVID-19 on the work procedures and working environment of staff at the University of Iceland]. Háskóli Íslands, Menntavísindasvið. https://www.hi.is/sites/default/files/ingunney/ahrifcovid19_hi_loka.pdf

Hafsteinsson, H., Rögnvaldsson, E., Freysteinsdóttir, F., Geirsdóttir, G., Ómarsdóttir, S. S. \& Jakobsdóttir, S. (2013). Skýrsla starfshóps háskólaráds um vefstudda kennslu og nám [Report by the University Council Workshop on web-assisted teaching and studies]. Háskóli Íslands. https://www.hi.is/sites/default/files/atli/ pdf/gamalt/mooc_skyrsla_endanleg_mai2013_4.pdf

Handal, G. (1999). Kritiske venner: Bruk af interkollegial kritik innan universiteten. Institutionen för systemteknik, Linköping University.

Háskóli Íslands. (2018). Stefna Háskóla Íslands um gaði náms og kennslu 2018-2021 [University of Iceland strategy with regard to quality of teaching and studies]. https://www.hi.is/sites/default/files/petura/7a_ stefna_hi_um_gaedi_nams_og_kennslu_2018-2021_-_26okt18_end.pdf

Háskóli Íslands. (2020). Könnun á atvinnuhorfum og líðan háskólanema [Inquiry into university students’ wellbeing and employment prospects]. https:/www.hi.is/frettir/konnun_a_atvinnuhorfum_og_lidan_haskolanema

Haynes, P., Ip, K., Saintas, P., Stanier, S., Palmer, H., Thomas, N., Reast, G., Barlow, J., \& Maillardet, F. (2004). Responding to technological change: IT skills and the academic teaching profession. Active Learning in Higher Education, 5(2), 152-165.

Hodges, C., Moore, S., Lockee, B., Trust, T., \& Bond, A. (2020). The difference between emergency remote teaching and online learning. EDUCAUSE. https://er.educause.edu/articles/2020/3/the-difference-between-emergencyremote-teaching-and-online-learning

Jóhannesson, I. Á. (2006). Looking for contradictions: Procedures in discourse analysis. Disability, ideas and methods in a new discipline. Háskólaútgáfan.

Jóhannsdóttir, P., \& Jakobsdóttir, S. (2010). Próun samkennslu staðnema og fjarnema við Menntavísindasvið Háskóla Íslands [The development of joint on-campus and distance teaching at the School of Education, University of Iceland]. Rádstefnurit Netlu-Menntakvika 2010. https://netla.hi.is/serrit/2010/mennta kvika2010/alm/030.pdf

Juan, A. A., Steegmann, C., Huertas, A., Martinez, M. J., \& Simosa, J. (2011). Teaching mathematics online in the European area of higher education: An instructor's point of view. International Journal of Mathematical Education in Science and Technology, 42(2), 141-153. https://doi.org/10.1080/0020739X.2010.526254

Kebritchi, M., Lipschuetz, A., \& Santiague, L. (2017). Issues and challenges for teaching successful online courses in higher education: A literature review. Journal of Educational Technology Systems, 46(1), 4-29. https://doi.org/10.1177/004723951666171 
Kember, D., \& Kwan, K. P. (2002). Lecturers' approaches to teaching and their relationship to conceptions of good teaching. In N. Hativa \& P. Goodyear (Eds.), Teacher thinking, beliefs and knowledge in higher education, 219-239. Kluwer Academic Publishers. https://doi.org/10.1007/978-94-010-0593-7_10

Kirkup, G., \& Kirkwood, A. (2005). Information and communications technologies (ICT) in higher education teaching - a tale of gradualism rather than revolution, Learning, Media and Technology, 30(2), 185-199. https://doi.org/10.1080/17439880500093810

Klemenčič, M. (2021). Students as actors and agents in student-centered higher education. In S. Hoidn \& M. Klemenčič (Eds.), The Routledge international handbook of student-centered learning and teaching in higher education (pp. 92-109). Routledge.

Kugel, P. (1993). How professors develop as teachers. Studies in Higher Education, 18(3), 315-328.

Kukulska-Hulme, A. (2012). How should the higher education workforce adapt to advancements in technology for teaching and learning? The Internet and Higher Education, 14(4), 247-254. https://doi.org/10.1016/j. iheduc.2011.12.002

Lindblom-Ylänne, S., Trigwell, K., Nevgi, A. \& Ashwin, P. (2006). How approaches to teaching are affected by discipline and teaching context. Studies in Higher Education, 31(3), 285-298. https://doi.org/10.1080 /03075070600680539

Lloyd, A. (2009). Informing practice: Information experiences of ambulance officers in training and on road practice. Journal of Documentation, 65(3), 396-417. https://doi.org/10.1108/00220410910952401

Mann, S. J. (2008). Study, power and the university. Society for Research into Higher Education \& Open University Press.

Marton, F., \& Booth, S. A. (1997). The educational psychology series: Learning and awareness. Lawrence Erlbaum Associates Publishers.

Pataraia, N., Falconer, I., Margaryan, A., Littlejohn, A., \& Fincher, S. (2014). 'Who do you talk to about your teaching?’: Networking activities among university teachers. Frontline Learning Research, 2(2), 4-14. https://doi.org/10.14786/flr.v2i2.89

Postareff, L., Virtanen, V., Katajavuori, N., \& Lindblom-Ylänne, S. (2012). Academics' conceptions of assessment and their assessment practices. Studies in Educational Evaluation, 38(3-4), 84-92. https://doi. org/10.1016/j.stueduc.2012.06.003

Prosser, M., Trigwell, K., \& Taylor, P. (1999). A phenomenographic study of academics' conceptions of science learning and teaching. Learning and Instruction, 4(3), 217-232.

Reglur fyrir Háskóla Íslands [Regulations of the University of Iceland] nr. 569/2009.

Rienties, B., \& Hosein, A. (2015). Unpacking (in)formal learning in an academic development programme: A mixed-method social network perspective. International Journal for Academic Development, 20(2), 163-177. https://doi.org/10.1080/1360144X.2015.1029928

Rodgers, R., Christie, J., \& Wideman, M. (2014). The effects of a required faculty development program on novice faculty self-efficacy and teaching. Higher Education Quality Council of Ontario.

Roxå, T., \& Mårtensson, K. (2009). Significant conversations and significant networks - exploring the backstage of the teaching arena. Studies in Higher Education, 34(5), 547-559. https://doi.org/10.1080/03075070802597200

Samuelowicz, K., \& Bain, J. D. (2001). Revisiting academics' beliefs about teaching and learning. Higher Education, 41(3), 299-325.

Schön, D. A. (1983). The reflective practitioner. Basic Books.

Sigurgeirsdóttir, S., \& Jóhannesdóttir, S. (2020). Úr stað- og fjarnámskennslu í fjarnám á meistarastigi. Breytingar á námskeiðinu Opinber stjórnsýsla 2019 [From on-campus and distance education to a master's by distance. Alterations to the course on state governance]. Tímarit Kennslumiðstöðvar Háskóla Íslands, 8(1), 54-55. https://doi.org/10.33112/tk.8.1

Stensaker, B., van der Vaart, R., Solbrekke, T. D., \& Wittek, L. (2017). The expansion of academic development: The challenges of organizational coordination and collaboration. In B. Stensaker, G. T. Bilbow, L. Breslow, \& R. van der Vaart (Eds.), Strengthening teaching and learning in research universities. Strategies and initiatives for institutional change (pp. 19-41). Palgrave/Macmillan. 
Stúdentaráð Háskóla Íslands. (2020a). Fyrstu niðurstöður könnunar Stúdentaráðs vegna COVID-19 [First results of Student Council inquiry inquiry into COVID-19]. https://student.backend.jldevelopment.is/wp-content/ uploads/2021/01/2-Konnun-22.-mars.pdf

Stúdentaráð Háskóla Íslands. (2020b). Niðurstöður priðju könnunar vegna sumarstarfa og atvinnu stúdenta [Results of Student Council third inquiry into student employment and summer jobs]. https://student. backend.jldevelopment.is/wp-content/uploads/2021/01/4-Konnun-4.-mai.pdf

Stuhmcke, A., Booth, T. P., \& Wangmann, J. M. (2016). The illusory dichotomy of plagiarism. Assessment \& Evaluation in Higher Education, 41(7), 1-14. https://doi.org/10.1080/02602938.2015.1053428

Stödberg, U. (2012). A research review of e-assessment. Assessment \& Evaluation in Higher Education, 37(5), 591-604. https://doi.org/10.1080/02602938.2011.557496

Taylor, J. (2011). The intimate insider: Negotiating the ethics of friendship when doing insider research. Qualitative Research, 11(1), 3-22. https://doi.org/10.1177/1468794110384447

Van Waes, S., Moolenaar, N. M., Daly, A. J., Heldens, H., Donche, V., Van Petegem, P., \& Van den Bossche, P. (2016). The networked instructor: The quality of networks in different stages of professional development. Teaching and Teacher Education, 59, 295-308. https://doi.org/10.1016/j.tate.2016.05.022

Watanabe, T. (2002). Learning from Japanese lesson study. Educational Leadership, 59(6), 36-39.

Weimer, M. (2002). Learner-centered teaching: Five key changes to practice. Jossey-Bass.

Wennergren, A. (2016). Teachers as learners - with a little help from a critical friend. Educational Action Research, 24(2), 260-279. https://doi.org/10.1080/09650792.2015.1058170

White, M. (2017). Towards a political theory of the university: Public reason, democracy and higher education. Routledge.

Yeo, M., \& Boman, J. (2019). Disciplinary approaches to assessment. Journal of Further and Higher Education, 43(4), 482-493. https://doi.org/10.1080/0309877X.2017.1367371

Pórsteinsdóttir, G. R., Prándardóttir, E., Ólafsson, R., \& Knútsson, Ö. (2007). Fjarnám við islenska háskóla: Uttekt og stöðugreining [Distance learning at Icelandic universities; assessment and situation analysis]. Rannsókna- og próunarmiðstöð Háskólans á Akureyri. https://rafhladan.is/bitstream/handle/10802/6431/ fjarnam_isl_hask_lokask.pdf?sequence=1

Guðrún Geirsdóttir, Marco Solimene, Ragna Kemp Haraldsdóttir and Thamar Heijstra. (2020).

Surfing a Steep Learning Curve: Academics' experience of changing teaching and assessment due to COVID-19

Netla - Veftímarit um uppeldi og menntun: Sérrit 2020 - Menntakerfi og heimili á tímum COVID-19

Sótt af http://netla.hi.is/serrit/2020/menntakerfi_heimili_covid19/11.pdf

DOI: https://doi.org/10.24270/serritnetla.2020.24 